\title{
等価回路網モデルを用いた室圧制御室の外乱による 圧力変動の予測*
}

\author{
山口太朗 ${ }^{* 1}$, 古川悠 ${ }^{* 2}$, 近藤明 ${ }^{* 3}$, 加賀昭和 ${ }^{* 4}$
Prediction of Pressure Change in Pressurized Rooms due to External Factors by Using an Equivalent Circuit Network Model

\author{
Taro YAMAGUCHI ${ }^{* 1}$, Yu KOGAWA, Akira KONDO and Akikazu KAGA \\ $*^{1}$ Researcher, Dai-Dan co., Ltd. \\ Kitanagai 390, Miyoshi-cho, Iruma-gun, Saitama, 354-0044 Japan
}

\begin{abstract}
We have proposed a new technique for predicting room pressure and duct pressure in pressurized clean rooms. In our technique, the pressure propagation mechanism is replaced with an equivalent electrical circuit network by considering the airflow rate as electrical current, the pressure as electrical potential, and the friction loss as an electrical resistance.In this paper our technique was applied to two pressure change situations caused by external factors. One was pressure change with starting and stopping of the local exhaust ventilation. The other was pressure change with starting of the ventilation equipment. By comparing the predicted results with experimental ones, we verified the validity of our method. Using this technique, the air-conditioning equipment can be evaluated under dynamic usage and the specification of the control devices can be optimized. The effectiveness of any newidea or new control algorithm for maintaining a stable system response can be also examined.
\end{abstract}

Key Words : Air Conditioning, Clean Room, Pipe Flow, Fluctuating Pressure, Pressure Control, Numerical Simulation, Contamination, Disturbance

\section{1. 緒言}

クリーンルームは清浄度管理に重点を於いた室であり，室内を外部より陽圧化させ，その圧力を一定に維持す ることで清浄環境であることを保証している。この室内圧力と基準点の圧力との差を「室圧」と呼ぶ．さらに， クリーンルームだけでなく，周囲の関連する部屋や廊下も含めたゾーンで室圧の順位を設ける「室圧計画」は， クリーンルームにおける污染防止のための重要な換気設計手法である. 図 1 はゾーン内での室圧計画の一例であ り，陽圧化のレベルを非常に強く「+++」，強く「十+」，一般領域よりもやや強く「十」，一般領域程度「 $\pm 0 」$ などの圧力差の度合いで表現している.

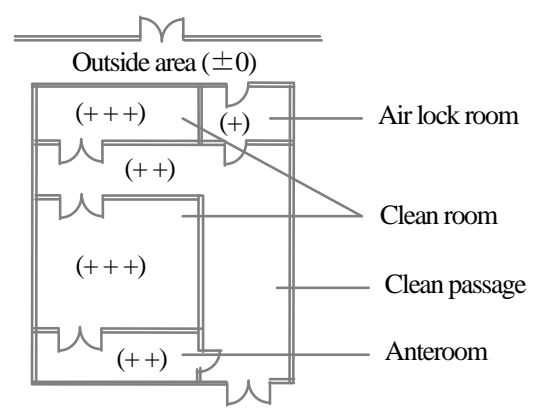

Fig. 1 Room pressurization plan example

\footnotetext{
* 原稿受付 2010 年 10 月 20 日

*1 正員, ダイダン (株)（厂354-0044 埼玉県入間郡三芳町北永井 390)

*2 ダイダン (株)

*3 正員, 大阪大学 工学部（广565-0871 大阪府吹田市山田丘 2-1S4 棟）

${ }^{* 4}$ 大阪大学 工学部

E-mail: yamaguchitaro@daidan.co.jp 
室圧計画通りの陽圧化を行うために空調設備の設計には，エアバランス(部屋への風量収支)の調整や最適な室 圧制御システムの構築が求められる。この設計時点では, 運用状況は定常状態であるとの前提で制御機器などの 仕様決定が行われるのが通例である.

一方で，実際の運用になると，空調システムは停止状態からの立上げや，非運用状態用の風量低下モードへの 切替え，生産装置や実験装置に付属する局所排気用のファンの運転・停止，扉の開閉など，室圧制御システムに よる室圧形成に対して外乱となる要素が多数ある. 近年では, 設計条件では考慮しきれない運用上の状態変化が 起こった際にも，設定された室圧が維持できることが施設運用における清净環境の管理に求められるようになっ てきた.

運用上の操作による状態変化により外乱が起こった場合でも, 室間の差圧順位が逆転しないように空調システ ムを設計するためには, 室圧やダクト系の圧力変動を予測し評価することが求められる. 空調システムのシミュ レーションツールとしては, HVACSIM $+{ }^{(1)}$ があり主に温度変化の動特性を建物とその空調設備全体で解くことが できる. その中で，ダクト・管路内の圧力変動を解くことができる. しかし，HVACSIM十は一般的な居室を対 象としたツールであり, 気密性の高いクリーンルームでの室圧変動は対象とされてない，また，温度変化と圧力 変動はタイムスールが大きく異なり，動的な現象解析を行う場合に同時に扱うと煩雑になる．管路の圧力変動を 解く試みとしては，水道網を対象とした管路網解析(2)がよく知られている．管路を各要素に分割し，その接点の 圧力と, その接点間の流量を変数として解析されている. 空調用のダクトや配管についても応用されている( ${ }^{(3)}$. しかし管路網解析を用いた場合も，部屋は圧力が一定の開放空間と見なされており，室圧変動を含めたモデル化 は行われていない. 気密性が高く, 漏気を想定するクリーンルームをモデル化し解析要素に取り込んだ場合, 管 路は閉回路となり数值解法は簡単でなくなる. 特に製薬施設のクリーンルームは多室間での室圧制御が行われて いるため，回路網が複雑な場合でも対応可能なモデルが必要である.

山下, 後藤, 山崎 ${ }^{(4)}$ は室間の漏気抵抗から室圧変動をモデル化した. しかし， 2 次方程式の解の公式による解法 を用いているため, ファンの特性曲線など全てを 2 次式で与える必要があった. ASHRAE ${ }^{(5)}$ や Wei ${ }^{(6)}$ による, 室 圧変動は漏気量の 1.3 次の特性があるとされている. 平間ら(フは, ダクト系や室内での圧力の伝達の遅れを再現す るため, 伝達関数を導入しラプラス変換を用いて, 部屋やダクト・チャンバなどを分布常数系として扱っている. 室圧変動のようにせいぜい $\pm 100 \mathrm{~Pa}$ 程度の圧力変化においては, 室内における圧力分布を詳細に把握するには及 ばない。

著者らは，管路と圧力制御室の室圧制御特性を電気回路の等価回路網に置き換えることで，ダクト系と室圧変 動を同時に考慮して計算できる新しいシミュレーション手法を提案し, 扉の開閉に伴う圧力変動現象に適用して, 実験結果との比較によりその有用性を検証した ${ }^{(8)}$. 新しい提案手法は, 従来法である管路網計算に比べて, 解く べき変数を大きく減らすことで計算時間を大幅に短縮しており, 多室の室圧制御にも適用可能である. 本報では, 提案手法を局所排気ファンの起動・停止と, 空調設備の給排気ファンの起動に伴う室圧変動に適用して, 実験結 果と比較することにより，手法の有用性をさらに確認するとともに，制御特性に及ぼす制御機器の動作速度の影 響や，制御アルゴリズムについて検討した結果について報告する.

\section{2. 室王変動における主な外乱}

室圧制御に影響を与える要因としては, 扉の開閉やファンの操作など人為的なものと屋外風の変化など自然発 生のものがある(9). 扉の開閉動作は, 室内の運用中に起きるものであり, 直接的なコンタミネーションのリスク を伴う重要な課題であることから, 多方面の研究があり, 著者らもその解決方法(8)(10)(11)を示している. 室内の運 用準備・非運用への切替えに伴って行う, 局所排気装置用のファンの起動・停止や, 給気風量(換気回数)の設定 変更，燻蒸操作のための空調機の起動・停止などの人為的な影響要因で生じる室圧の大きな変動は，隣室との差 圧の逆転を引き起こし, その結果, 無塵・無菌状態の維持や管理物質の完全封じ込めが保証できなくなる. また, 屋外風の変化により建物に吹き付ける風による作用で室圧制御が安定せず，許容範囲内に収まらない場合がある (12),(13) .

本報では, 人為的な影響要因である局所排気ファンの起動・停止と, 空調設備の給排気ファンの起動に伴う室 圧変動について取り上げた。 


\section{3. 局所排気ファンの起動亭止二伴う室圧変動}

\section{$3 \cdot 1$ 実験概要}

局所排気ファンは，室内の清浄環境保持のためではなく，生産装置からの排熱や，生産時の余剩物の排出のた めに用いられる.つまり, 生産稼働時には必要であるが, 生産準備中などの非生産時には稼働させる必要がなく, 省エネの観点から停止させておくべきものである. しかし, 局所排気装置の起動停止に伴い大きな圧力変動が起 きてしまうため, 非生産時でも停止させない運用を行う施設が多い，その為，局所排気ファンの起動停止におい ても圧力変動を緩和できる対策を検討することが重要となる.

まず，局所排気ファンの起動停止に伴う室圧变動に対して，我々の手法の有効性を実験值と比較し検証する. 検証環境のダクト系統は, 図 2 に示寸ように二部屋のうち Room2 側に局所排気ファンを設置したものである.こ こで, CAV は Constant Air Volume unit の略称で，風量が設定值となるようにダンパが開閉する装置である. PCD は Pressure Control Damper の略称で，検出圧が設定值となるようにダンパが開閉する装置である．また，検証環 境の設備の様子を図 $2 \mathrm{~b}, \mathrm{c}$ に，設備の仕様を表 1 に示寸。検証環境に用いたファンの特性曲線は図 3 のように，メ

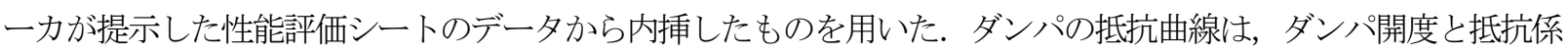
数について実測し図4のように内挿した. Room1, Room2 はそれぞれ 5 Pa，10 Pa の設定室圧で制御している. 時 刻 $30 \mathrm{~s}$ において局所排気ファンが停止状態から起動させ, 時刻 $90 \mathrm{~s}$ において停止させた場合について室圧変動を 実験とシミュレーションによる結果を比較した.

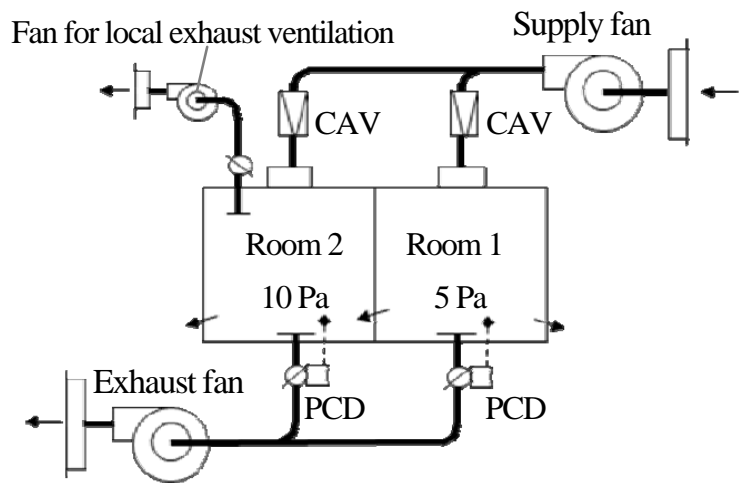

a) Schematic

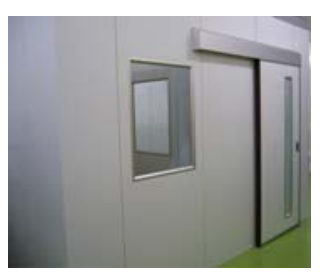

Rooms

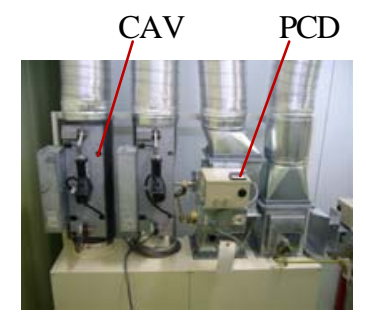

Control equipment

c) Extemals photograph
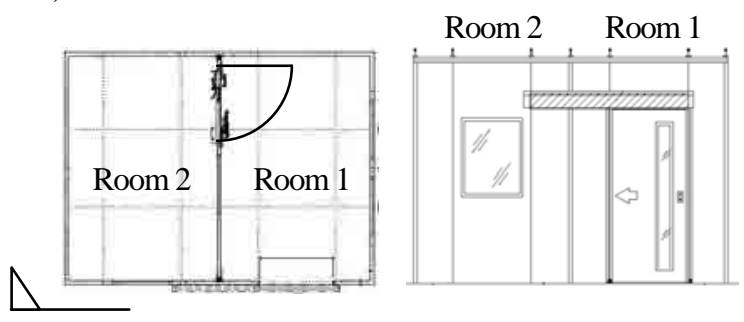

b) Plan of rooms

Fig. 2 Experimental air-conditioning equipment

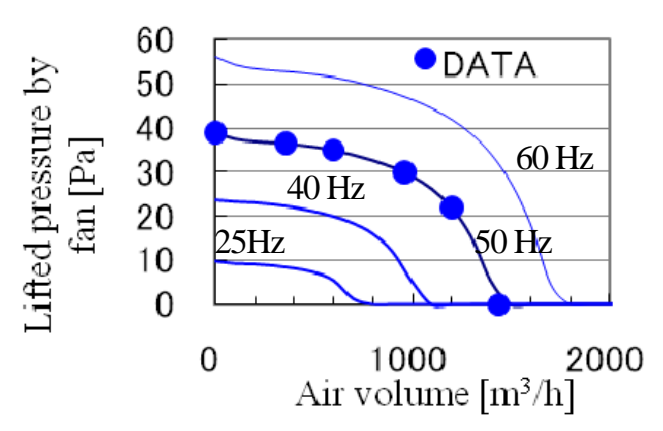

Fig. 3 Characteristics curve of fan output

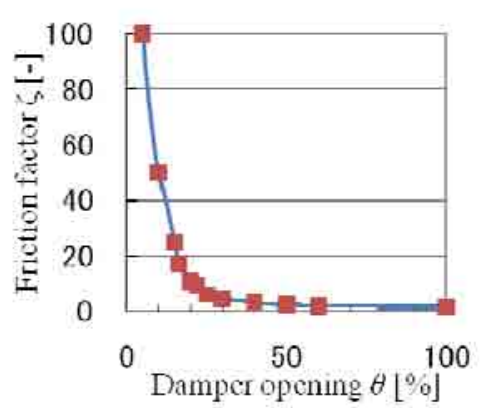

Fig. 4 Friction factor characteristics of pressure control dampers 
Table 1 Experimental conditions

\begin{tabular}{|c|c|c|}
\hline & Room1 & Room2 \\
\hline Room size & $2.7 \times 1.8 \times 2.6 \mathbf{m}$ & $2.7 \times 1.8 \times 2.6 \mathbf{m}$ \\
\hline Air volume & $420 \mathrm{~m}^{3} / \mathrm{h}$ & $470 \mathrm{~m}^{3} / \mathrm{h}$ \\
\hline Air change rate & $33.3 \mathrm{ACH}$ & 37.3 ACH \\
\hline Room pressure & $5 \mathrm{~Pa}$ & $10 \mathrm{~Pa}$ \\
\hline Supply air system & \multicolumn{2}{|c|}{$\begin{array}{l}\text { Fan: } 50 \mathrm{~Hz} \\
\text { Constant Air Volume unit(CAV) } \\
\text { damper speed :0.83\%/s } \\
\text { duct diameter: } 200 \mathrm{~mm}\end{array}$} \\
\hline Exhaust air system & \multicolumn{2}{|c|}{$\begin{array}{l}\text { Fan : } 60 \mathrm{~Hz} \\
\text { Pressure control damper (PCD) } \\
\quad \text { damper speed : } 1.7 \% / \mathrm{s} \\
\text { duct diameter : } 200 \mathrm{~mm}\end{array}$} \\
\hline $\begin{array}{l}\text { Local exhaust air } \\
\text { system }\end{array}$ & \multicolumn{2}{|c|}{$\begin{array}{l}189 \mathrm{~m}^{3} / \mathrm{h} \\
\text { duct diameter }: 100 \mathrm{~mm}\end{array}$} \\
\hline
\end{tabular}

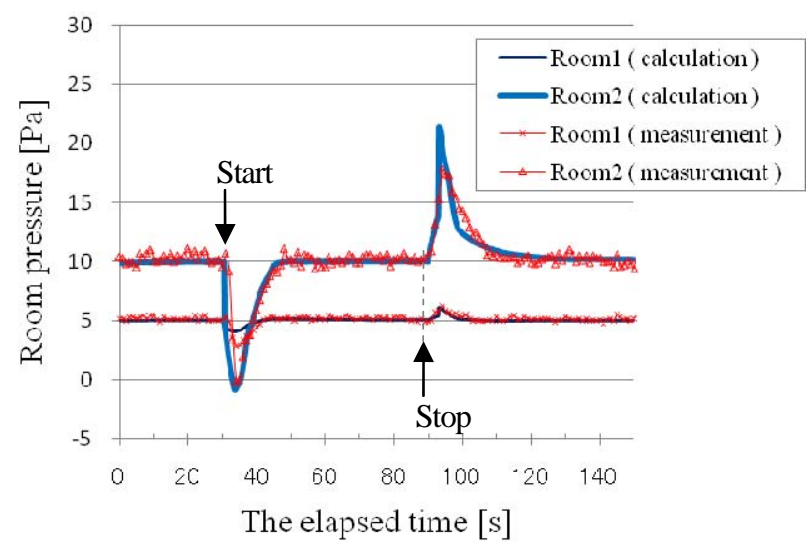

Fig. 5 Pressure change with starting and stopping of the local exhaust ventilation

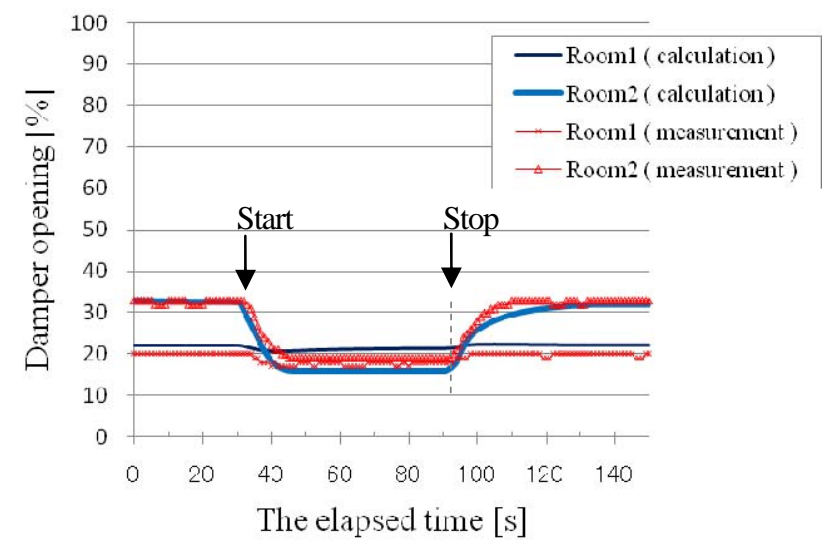

Fig. 6 Damper opening change with starting and stopping of the local exhaust ventilation

\section{3 - 2 実験とシミュレーションによる結果の比較}

実験結果および我々の手法でシミュレーションを行った結果の室圧変動を図 5 に, PCD のダンパ開度の变化を 図 6 に示す.

実験結果では，局所排気ファンが作動し始めた $30 \mathrm{~s}$ にRoom2 からの排気風量の総量が増えたため，室内の給 排気のバランスが崩れ Room2 の室圧が, -0.1 Pa まで低下し, その後, PCD が室圧の回復のために, 開度が 33\% か ら 20\% まで移行した. Room2 の室圧が低下している間, Room1 と Room2 との隙間を通じた漏気の影響で, Room1 
の室圧も $3.4 \mathrm{~Pa}$ まで低下した. 局所排気ファンが停止し始めた $90 \mathrm{~s}$ では, 給気風量の過多が起こり, Room1, Room2 の室圧が， 5.7 Pa, 17.8 Pa となり，その後それぞれの設定室圧に回復した.

計算結果は, 実験值の結果をよく一致しており, 圧力変動およびダンパの開度変化を再現した．ただし，以下 については差異がみられた. 一つ目として, 排気開始時の Room1 側の室圧の変化量が異なった. Room1 と Room2 間の漏気面積データが計算值では過小評価されたと考えられる. 二つ目として, 排気停止時の Room2 側の室圧変 化のピーク值が異なった．正確には確認できないが，実験值では検出器の反応遅れのため検出できなった圧力上 昇を再現していると考えられる. 三つ目は, 排気停止時の室圧回復過程における Room2 側のダンパ開度の変化状 況にずれがある点である. PCD の制御動作が設定した条件よりも, 偏差の小さい部分で実験值の方が早く動作し ているためと考えられる. 以上のように細部では差異があるが，室圧変化を予測する上で本手法が十分有効性を 発揮できることが確認できた.

\section{$3 \cdot 3$ 室圧変動を抑えるための対策検討}

次に室圧変動を抑えるための対策について, 圧力シミュレーションで検討する. PCD の動作速度を変化させた 場合における Room 2 の室圧変動のシミュレーションの結果を図 7 に示寸. PCD の動作速度は追従速度を意味し, 早ければ早いほど, 圧力変動後の復旧に要する時間が短くなる. しかし, PCDの動作はフィードバック制御であ るため, 圧力変動がある程度発生した後に発揮される機能であり，根本的に圧力変動そのものを解消するには至 らないことが分かった。

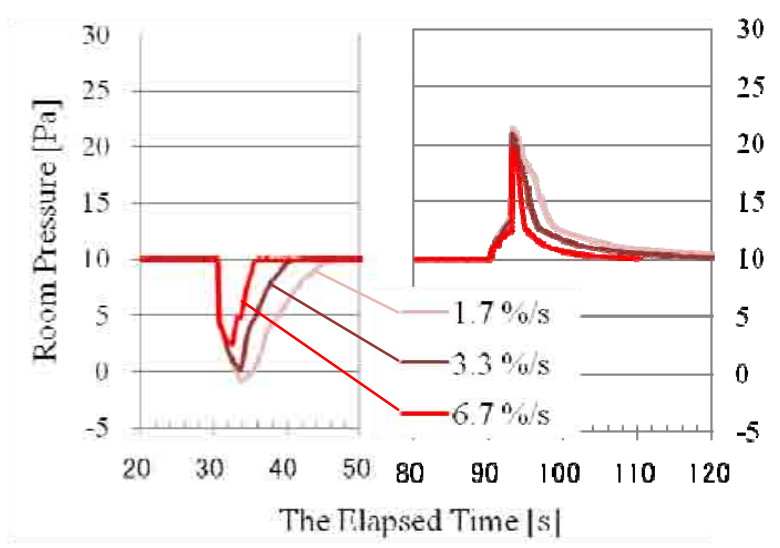

Fig. 7 Pressure change difference with different PCD speed

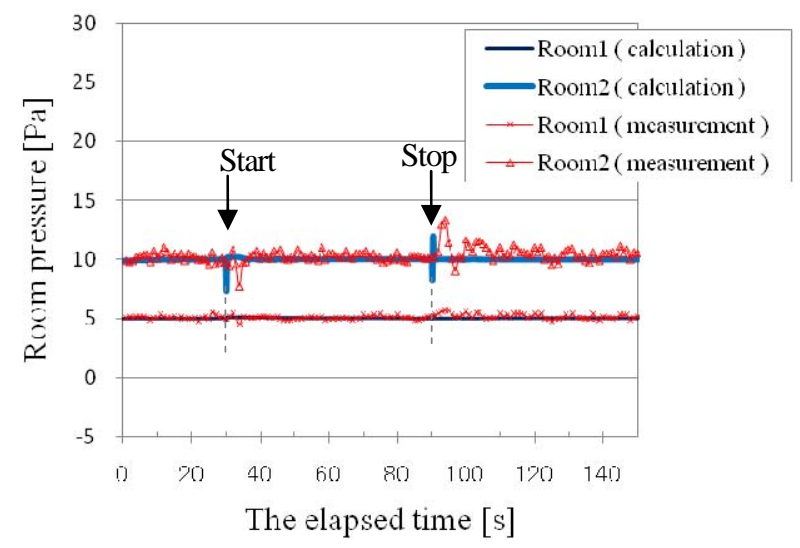

Fig. 9 Pressure change with applying the automatic control in Fig.8 


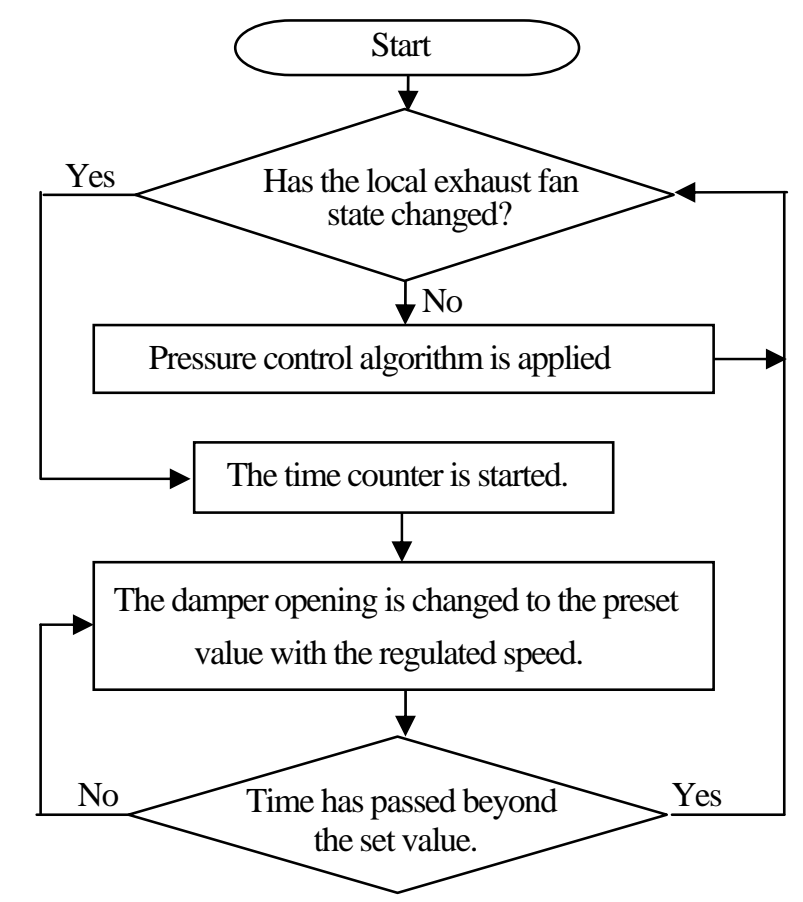

Fig. 8 Control flow that accompanies start and stop of the local exhaust ventilation.

次に，図 8 の制御フロー(14) に従って，PCD の制御動作を，排気装置の起動・停止の信号により，所定時間 $(5 \mathrm{~s})$ だけ外部信号で指定開度に動作させた場合の計算結果と，同条件で行った実験結果を図 9 に示寸，計算結果およ び実験結果から，圧力変動が抑制されることが示された，つまり，対策すべき事象について，予め本手法による シミュレーションを使って有効性を確認することで, 制御の妥当性を評価してから実施に移れることが示された.

\section{4. 給排気ファンの起動に伴う室圧変動}

\section{$4 \cdot 1$ 実験概要}

生産時に無菌環境が要求される製薬施設では，空調を停止して，ホルマリンなどの薬剤による燻蒸による滅菌 (除染)操作を行う。この除染された状態から，空調設備の給排気ファンを起動させて無菌状態を維持するための 室圧制御を行う。このとき, 空調設備の給排気ファンの起動に伴って大きな圧力変動が生じ, 室圧の順位の乱れ や周囲の他の居室・空間との室圧の逆転が生じると，除染の効果が保証されなくなる．さらに，過剩な圧力上昇 は, 壁面などの建材の接合部分に過剩な負荷をかけ，シール材の劣化を引き起こし，結果的に壁の倒壊を起こす ことがある.したがって，空調設備の起動時の圧力変動への対策を検討寸ることは重要である.

空調設備の給排気ファンの起動時の室圧変動に対して, 我々の手法を実験值と比較し, 圧力変動を再現可能で あることを検証する．検証環境のダクト系統および，設備の仕様は，先と同じく図 2 ，表 1 のものを用いた．給 気ファンおよび排気ファンが停止した状態から始め, 時刻 $0 \mathrm{~s}$ において給気ファンおよび排気ファンを同時に起 動させた場合について室圧変動を比較した.

\section{$4 \cdot 2$ 実験結果とシミュレーションによる計算結果の比較}

実験結果およびシミュレーションを行った結果の室圧変動を図 10 に示寸．また PCD のダンパ開度の変化を図 11 に示寸. 実験值・計算值ともに, 0s の空調設備の起動により Room 1 は 30 Pa まで, Room2 は 70 Pa まで圧力 が過剩に上昇し, $30 \mathrm{~s}$ 後にそれぞれの設定圧力となった. 開度の変化をみると, 室圧が設定值を超える $2 \mathrm{~s}$ まで はPCD のダンパ開度が全閉であり，その後徐々に開いて，定常状態で各室圧が設定值になる開度 $20 \%, 32 \% に$ 収 束した. つまり, 給排気ファンの起動時には, 排気側の PCD の開度が定常時の開度と大きく乘離しているために 室圧の過剩な上昇を起こしている. PCD はフィードバック制御により圧力の上昇が緩和される方向に動くが，フ 
アンの回転数の上昇による風量の上昇の速度に追いついていないため, 設定室圧への到達までに時間を要してい ることが分かった。

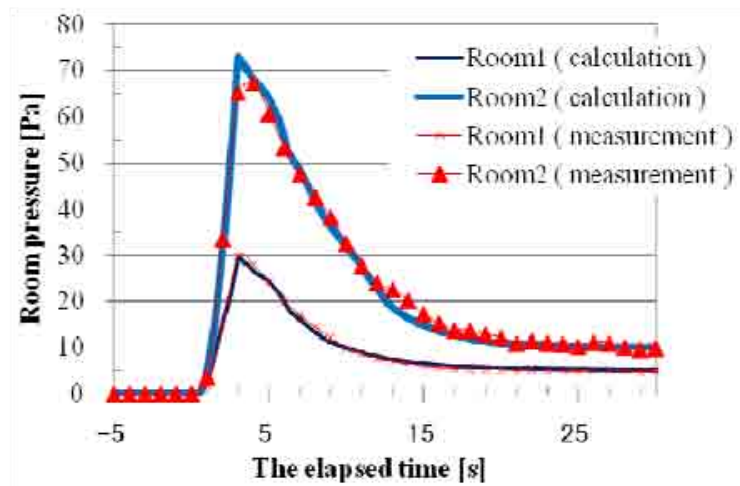

Fig. 10 Pressure change with starting of the ventilation equipment

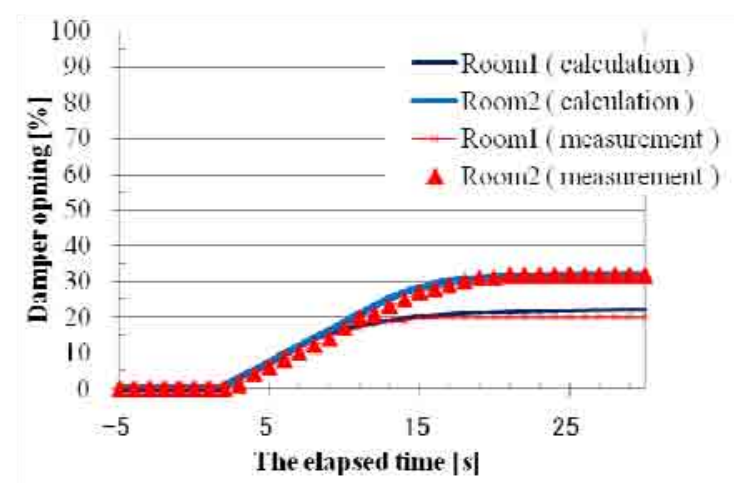

Fig. 11 Damper opening change with starting of the ventilation equipment

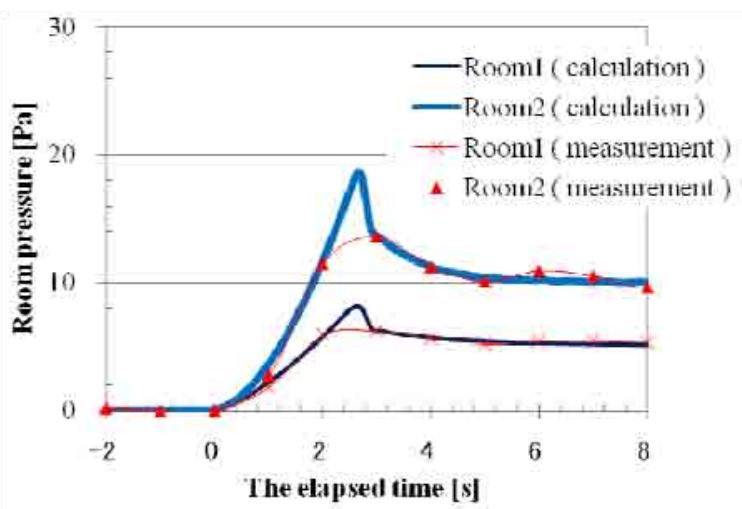

Fig. 12 Pressure change with accompanying a damper opening operation

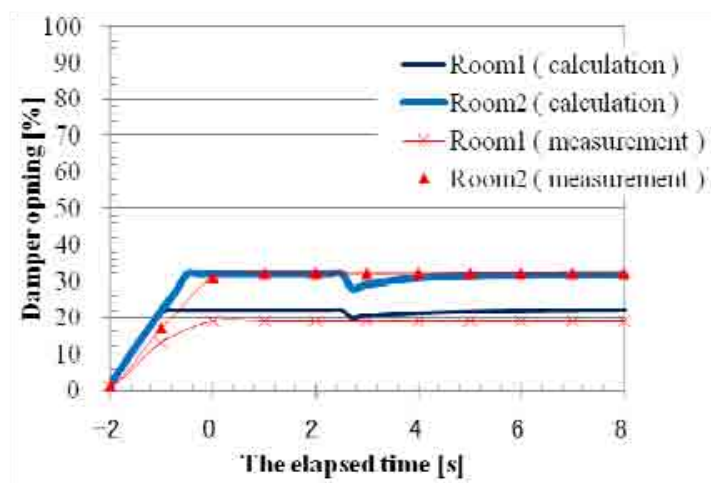

Fig. 13 Damper opening change with accompanying a damper opening operation 


\section{$4 \cdot 3$ 室圧変動を抑えるための対策検討}

次に室圧変動を抑えるための対策について, シミュレーションで検討する. 空調設備の起動に伴って, PCD の 開度を定常時に設定室圧となる開度まで動作をさせた場合 ${ }^{(15)}$ の室圧変動のシミュレーションと実験の結果を図 12, 13 に示す. 圧力上昇は Room1 では 8 Pa 以下，Room2 では 20 Pa に抑えられ，対策が効果的であることが示 された．また，計算値との比較から，実験值ではピークの值が計測のインターバルによって検出されていないこ とも推定された.

\section{5. 結語}

我々は, 多室のクリーンルームにおける圧力変化を予測するための，等価回路網を用いた新しい計算手法を提 案している. 本報では室圧変動を生じさせる外乱として，局所排気ファンの起動停止時および空調設備の給排気 ファンの起動時の二例を取り上げ，本手法による計算結果と実験結果を比較し，十分一致した結果を得ることを 確認し，我々の手法が有効であると判断した．我々の手法を使うことで，室圧変動を抑えるための対策方法につ いて有効性を確認できることを示した.

\section{文献}

(1) 鄭明傑, 西谷義彦, 林茂広, 中原信生, " 動的シミュレーションHVACSIM+の再現性の検証とパラメータの 調整に関する研究", 空気調和・衛生工学会論文集, No.75 (1999), pp. 39-48.

（2）日本機械学会編, "技術資料 管路・ダクトの流体抵抗 (2004)", 日本機械学会.

(3) 坂東修, "Ecxel で解く配管とポンプの流れ (2008)", 工業調査会.

(4) 山崎一彦, 後藤立夫, 山崎均, "室・ダクト系の空調システムシミュレーション", 空気調和・衛生工学会論文 集, No.70 (1998), pp. 9-19.

(5) American Society of Heating, Refrigerating and Air-Conditioning Engineers ed., ASHRAE Handbook-Fundamentals, (2009), Chapter 16, 14 Residential Are Leakage.

(6) Wei, S., "Quantitative Multistage Pressurizations in Controlled and Critical Environments", ASHRAE Transactions , Vol.110, Part.2 (2004), pp.759-769.

(7) 平間一歩, 田中伸宏, 三宅孝之, 立野繁之, 松山久義, "空調設備における室圧制御系設計審査用シミュレー 夕の開発", 電子情報通信学会技術研究報告 (2007). R, 信頼性 Vol.107, No.270, pp.31-36.

(8) Yamaguchi, T., Kaga, A. and Kondo, A.,"Prediction Technique for Pressure Change in Rooms by Using an Equivalent Circuit Network", Journal of Environment and Engineering, Vol.5, No.2 (2010), pp.444-455.

(9) 助宮賢治, "室圧制御に影響を与える要因と対策", PDA Journal of GMP and Validation in Japan, Vol.1, No.1 (1999), pp.45-51.

(10) 山口太朗, 吉田一也, 長谷川雅一, "クリーンルームにおける扉開閉に伴うクロスコンタミネーションの制 御手法とその効果検証", 空気調和・衛生工学会論文集, No.138 (2008), pp.9-17.

(11) Yamaguchi, T., Kondo, A. and Kaga, A, "Study on Doorway Airflow for Maintaining Clean Environment", International Symposium on Contamination Control 2010 Tokyo (2010), pp.210-215.

(12) 助宮賢治, 森岡宏次, "建物周囲の風圧変動が製剤施設の室圧に与える影響に関する研究(第 1 報 台風下に おける測定結果)", 空気調和・衛生工学会学術講演論文集 (1997), pp.1-4.

（13）古川悠, 山口太朗, 佐々木洋二, "室圧に対する屋外風の影響に関寸る研究（第 1 報）給気系統に屋外風が 作用する場合の実験検証とシミュレーション", 空気調和・衛生工学会学術講演論文集 (2010), pp.373-376.

(14) 山口太朗, 長谷川雅一, 橋本明洋, "室圧制御方法およびその装置", 日本国特許第 4485476 号 (2006).

(15) 山口太朗, 三浦祐一, "室圧制御システム", 日本国特開第 2009-47379 号 (2009). 